\title{
Preliminary pharmacognostical and phytochemical evaluation of Stachys tibetica Vatke
}

Dinesh Kumar ${ }^{1}$, Zulfiqar Ali Bhat ${ }^{1}$, Vijender Kumar ${ }^{1}$, Ishtaq Ahmad Chashoo ${ }^{1}$, Nisar Ahmad Khan $^{1}$, Irfat Ara ${ }^{2}$, Mohammad Yassin Shah ${ }^{1}$

${ }^{1}$ Department of Pharmaceutical sciences, University of Kashmir-190006, India $;{ }^{2}$ CCRUM, Srinagar-190006, India

\begin{abstract}
Stachys tibetica Vatke (Lamiaceae) is an important medicinal plant in the folk medicine of Ladakh, India and Tibet for the treatment of various mental disorders. Infusion and decoction of the whole plant is used as a cup of tea for a severe fever, headaches and to relieve tension. The recent study is aimed to evaluate the preliminary pharmacognostical and phytochemical nature of Stachys tibetica Vatke. The whole plant material was subjected to successive soxhlet extraction with petroleum ether $\left(40-60^{\circ} \mathrm{C}\right)$, chloroform, ethyl acetate, methanol and finally decocted with water to get the respective extracts. The fluorescence characteristics of the powdered materials were analysed under ultraviolet light and ordinary light. Different physicochemical parameters such as ash value, extractive value, foaming index, $\mathrm{pH}$ values, loss on drying and determination of foreign matter were carried out as per WHO guidelines. The total fat, flavonoid, saponin and volatile contents were also determined. Macroscopical studies revealed the authentication of the plant drug. Physicochemical parameters helped to standardize the plant material while preliminary qualitative chemical tests of different extracts showed the presence of Glycosides, Carbohydrates, Phytosterols/triterpenoids, Saponins, Fixed oils, Fats and phenols/tannins. Quantification of the total flavonoids and saponins and contents were determined as $54.66 \pm 0.58 \mathrm{mg} / \mathrm{g}$ and $75.42 \pm 0.48$ $\mathrm{mg} / \mathrm{kg}$ respectively, while the volatile and fat contents were $6.5 \%$ and $0.7 \%$ respectively. Results may lay the foundation for the standardization of the drug and discovery of new molecules from $S$. tibetica for the treatment of various diseases.
\end{abstract}

Keywords Stachys tibetica, Lamiaceae, physicochemical, phytochemical, extraction

\section{INTRODUCTION}

The use of medicinal plants for the treatment of human diseases has increased considerably worldwide. Evaluation of the effects of these plants on organs and systems has contributed to the development of the scientific basis for their therapeutic applications and also has enriched considerably the therapeutic arsenal for the treatment of a number of diseases (Kumar et al., 2011). People of all ages in both developing and undeveloped countries use plants in an attempt to cure various diseases and to get relief from physical sufferings. Today, several medicinal plants and their products are still in use, being employed as home remedies, over the counter drugs as well as raw materials for the pharmaceutical industry and they represent a substantial proportion of the global drug market. However, a key obstacle, which has hindered the acceptance of the alternative medicines in the developed countries, is the lack of documentation and stringent quality control. There is a need for documentation of research work carried out on traditional medicines. Therefore, it has become extremely important to make an effort towards standardization of the plant material to be used as medicine. The process of standardization can be achieved by stepwise pharmacognostic studies (Mulla and Swamy, 2010).

Stachys L. (Lamiaceae) is a large genus of herbs and shrubs

*Correspondence: Zulfiqar Ali Bhat

E-mail: sharmadinesh82@gmail.com; zabhat2000@gmail.com

Received July 11, 2011; Accepted February 13, 2012; Published

February 29, 2012

doi: http://dx.doi.org/10.5667/tang.2011.0019

(C) 2012 by Association of Humanitas Medicine

TANG / www.e-tang.org comprising 300 species distributed in temperate and tropical regions of the world, with the exception of Australasia (Mabberley, 1997). Plants of this genus have been used in folk medicine for centuries to treat genital tumors, sclerosis of the spleen, inflammatory diseases, coughs and ulcers (Hartwell, 1982). S. tibetica is a herb distributed in tropical and subtropical regions of the world including Tibet, China, and India. In India it is found in the cold desert regions of Kargil, Ladakh Valley and in the mountains of Himachal Pradesh. The traditional practitioners in the Kargil and Ladakh regions of India use the drug for treatment of various mental disorders and phobias. In traditional practice, the whole plant is boiled and made into a decoction. A tea cup of the decoction is given twice a day to treat a fever (Ballabh and Chaurasia, 2007).

The present study is aimed to evaluate the preliminary pharmacognostical and phytochemical nature of Stachys tibetica Vatke. Investigations of various standardization parameters such as organoleptic, physico-chemical paramenter, fluorescence analysis, powdered drug reaction with different reagents, phytochemical screening and TLC analysis, saponin, fat, volatile and flavonoid contents can be helpful in the authentification of Stachys tibetica Vatke. The present study will also serve as reference material in preparation of the monograph.

\section{MATERIALS AND METHODS}

Collection of plant material and authentication 
Table 1. Solvent systems for Detection of chemical constituents/secondary metabolites in stachys tibetica vatke

\begin{tabular}{|c|c|c|c|c|c|c|c|}
\hline \multicolumn{2}{|c|}{ Steroids and their glycosides } & \multicolumn{2}{|c|}{ Flavanoids and their glycosides } & \multicolumn{2}{|c|}{ Alkaloids } & \multicolumn{2}{|c|}{ Saponins } \\
\hline Solvents & Proportion & Solvents & Proportion & Solvents & Proportion & Solvents & Proportion \\
\hline $\begin{array}{c}\text { EA : Methanol : } \\
\text { Water }\end{array}$ & $100: 13.5: 10$ & $\begin{array}{l}\text { Chloroform : } \\
\text { Methanol }\end{array}$ & $\begin{array}{c}80: 20,70: 30 \\
50: 50\end{array}$ & $\begin{array}{l}\text { Toulene : EA : } \\
\text { Diethylamine }\end{array}$ & $70: 20: 1$ & $\begin{array}{c}\text { Chloroform: } \\
\text { GAA : Methanol: } \\
\text { Water }\end{array}$ & $64: 32: 12: 8$ \\
\hline $\begin{array}{c}\text { EA : Methanol : } \\
\text { Water }\end{array}$ & $75: 15: 10$ & $\begin{array}{c}\text { EA : } \\
\text { Methanol : } \\
\text { Water }\end{array}$ & $81: 11: 8$ & $\begin{array}{c}\text { Toluene : EA : } \\
\text { FA }\end{array}$ & $5: 4: 1$ & $\begin{array}{c}\text { Hexane: EA : } \\
\text { methanol }\end{array}$ & $6: 3: 1$ \\
\hline $\begin{array}{c}\text { Chloroform : } \\
\text { Methanol : Water }\end{array}$ & $70: 30: 4$ & $\begin{array}{l}\text { n-Butanol : } \\
\text { AA : Water }\end{array}$ & $\begin{array}{c}4: 1: 5 \\
\text { (Upper phase) }\end{array}$ & & & & \\
\hline $\begin{array}{c}\text { n-Butanol : } \\
\text { Ethanol : Water }\end{array}$ & $40: 11: 9$ & $\begin{array}{c}\text { EA: FA: GAA : } \\
\text { Water }\end{array}$ & $100: 11: 11: 26$ & & & & \\
\hline Benzene : Ethanol & $4: 1$ & & & & & & \\
\hline
\end{tabular}

The plant specimen of Stachys tibetica Vatke was collected from the cold desert of Kargil and Ladakh, Jammu and Kashmir, India. The plant was identified and authenticated by the Department of Pharmaceutical Sciences, University of Kashmir as Specimen Voucher number-KUST01 by Sr. Asst. Prof. (Dr) Zulfiqar Ali Bhat, Srinagar-190006, India.

\section{Drying and size reduction of plant}

The whole plant material of Stachys tibetica was subjected to shade drying for about 1 week. The dried plant material was further crushed to powder and the powder was passed through mesh 40 and stored in an air tight container for further analysis.

\section{Organoleptic study of plant material}

In some cases, the general appearance of the herb is similar to related species. Thus, a detailed study of the morphological characters can be helpful in differentiating them. The organoleptic study of the drug includes its visual appearance to the naked eye along with its characteristics likes odour, taste, and texture. For each particular organoleptic group, a particular systemic examination can be carried out.

\section{Determination of physicochemical constants of plant materials}

\section{Extractive Values}

\section{Cold extractive values}

$4 \mathrm{~g}$ of air-dried coarse drug powder was macerated separately with solvents (petroleum ether, chloroform, ethyl acetate, methanol and water) of volume $100 \mathrm{ml}$ in a closed flask for 24 $\mathrm{h}$, shaking frequently during $6 \mathrm{~h}$ and allowed to stand for $24 \mathrm{~h}$. It was filtered rapidly, taking precaution against loss of solvent, and the filtrate evaporated to dryness in a tarred flat bottom dish and dried on a water bath, to a constant weight.

\section{Hot extraction values}

$100 \mathrm{~g}$ of powdered material of the drug was packed in a Soxhlet apparatus separately for each solvent like petroleum ether, chloroform, ethyl acetate and methanol, but in case of the water extract the drug was prepared by a decoction method. Each extract was evaporated to dryness and the constant extractive value recorded.

\section{Successive extractive values}

$100 \mathrm{~g}$ of dried and coarsely powdered material was subjected to successive extraction in a Soxhlet apparatus with different solvents like petroleum ether, chloroform ethyl acetate, methanol and in case of the water solvent, the drug was prepared by a decoction method. The extracts were evaporated to dryness and their constant extractive values recorded.

\section{Ash values}

\section{Total ash}

$1 \mathrm{~g}$ of the ground drug was incinerated in a silica crucible at a temperature not exceeding $450^{\circ} \mathrm{C}$ until free from carbon. It was then cooled and weighed to get the total ash content.

\section{Acid insoluble ash}

Ash was boiled with $25 \mathrm{ml}$ dilute $\mathrm{HCl}(2 \mathrm{~N})$ for $5 \mathrm{~min}$. The insoluble matter was collected on an ashless filter paper, washed with hot water and ignited at a temperature not exceeding $450^{\circ} \mathrm{C}$ to a constant weight.

\section{Water-soluble ash}

Ash was dissolved in distilled water and the insoluble part collected on an ashless filter paper and ignited at $450^{\circ} \mathrm{C}$ to a constant weight. By subtracting the weight of the insoluble part from that of the ash, the weight of the soluble part of the ash was obtained.

\section{Foreign matter}

Foreign matter in the crude drugs can be due to faulty collection or deliberate mixing. It was separated from the crude drugs and the percentages calculated.

\section{Loss on drying}

$100 \mathrm{~g}$ of powdered drug sample without preliminary drying was placed on a tarred evaporating dish and dried at $105^{\circ} \mathrm{C}$ for $6 \mathrm{~h}$ and weighed. The drying was continued until two successive readings matched each other or the difference between two successive weighings was not more than $0.25 \%$. A constant weight was reached when two consecutive weighings after

\begin{tabular}{|c|c|c|c|c|}
\hline & Fresh Leaf & Stem & Flower & Root \\
\hline Color & Green & light green & White pink & Brown \\
\hline Odor & Aromatic & Aromatic & Aromatic & Muddy \\
\hline Taste & Bitter & Bitter & Characteristics & Bitter \\
\hline Texture & Characteristics & Acute and brittle & - & Horny and hard \\
\hline Shape & $\begin{array}{l}\text { Bipinnate, Margin of the leaf is entire and apex } \\
\text { is short. }\end{array}$ & - & $\begin{array}{l}\text { Corolla, calyx is tubular/ } \\
\text { campanulate }\end{array}$ & Cylindrical and snake like \\
\hline Size & $\begin{array}{l}0.8 \text { to } 4.8 \mathrm{~cm} \text { in length and } 0.1 \text { to } 0.3 \mathrm{~cm} \text { in } \\
\text { breadth }\end{array}$ & - & - & - \\
\hline
\end{tabular}




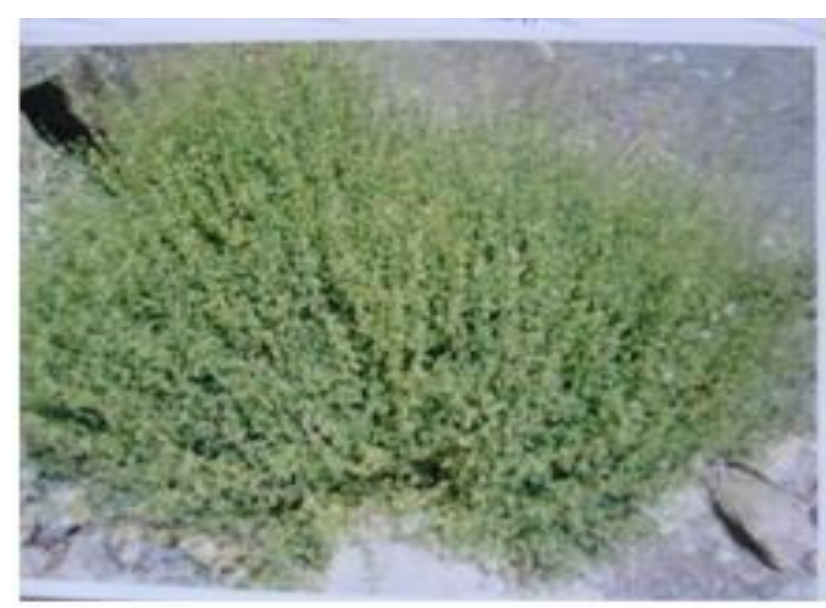

Fig. 1. Plant Stachys tibetica Vatke.

drying for $30 \mathrm{~min}$ in a desicator showed not more than a $0.01 \mathrm{~g}$ difference.

\section{Swelling index}

$3 \mathrm{~g}$ of a specified quantity of plant material previously reduced to the required fineness and accurately weighed was put into a $25 \mathrm{ml}$ glass stoppered measuring cylinder. $25 \mathrm{ml}$ of water was added and the mixture was shaken thoroughly every $10 \mathrm{~min}$ for $1 \mathrm{~h}$. It was allowed to stand for $3 \mathrm{~h}$ at room temperature. The mean value of the individual determination was calculated related to $1 \mathrm{~g}$ of plant material.

\section{Foaming index}

About $1 \mathrm{~g}$ of the plant material was reduced to a coarse powder, weighed accurately and transferred to a $500 \mathrm{ml}$ conical flask containing $100 \mathrm{ml}$ of boiling water. It was maintained at moderate boiling for $30 \mathrm{~min}$, cooled and filtered into a $100 \mathrm{ml}$ volumetric flask. Sufficient water was added through the filter paper to dilute to volume. The decoction was poured into 10 stoppered test tubes in successive portions of $1 \mathrm{ml}, 2 \mathrm{ml}, 3 \mathrm{ml}$ up to $10 \mathrm{ml}$. The volumes in these test tubes were mixed with water up to $10 \mathrm{ml}$. The test tubes were stoppered and shaken in a lengthwise motion for $15 \mathrm{~s}, 2$ shakes per second. It was allowed to stand for $15 \mathrm{~min}$., the height of the foam measured and foam index calculated (Anonymous, 1998).

\section{Determination of $\mathbf{p H}$}

\section{pH 1\% solution}

Dissolved accurately weighed $10 \mathrm{~g}$ of the drug in accurately measured $100 \mathrm{ml}$ of distilled water, filtered and $\mathrm{pH}$ of the filtrate checked with a standardized glass electrode.

\section{pH $10 \%$ solution}

Dissolved accurately weighed $10 \mathrm{~g}$ of the drug in accurately

Table 3. Extractive Values of Stachys tibetica Vatke

\begin{tabular}{lcccc}
\hline Solvents & $\begin{array}{l}\text { Cold extractive } \\
\text { values } \\
\text { (Individual) } \\
\text { yield (w/w) }\end{array}$ & $\begin{array}{l}\text { Hot } \\
\text { values } \\
\text { (Individual) } \\
\text { yield (w/w) }\end{array}$ & $\begin{array}{l}\text { \% } \\
\text { \% }\end{array}$ & $\begin{array}{l}\text { extractive } \\
\text { values } \\
\text { yield (w/w) }\end{array}$ \\
\hline $\begin{array}{l}\text { Petroleum } \\
\text { ether } \\
\left.\mathbf{( 4 0}-\mathbf{6 0}^{\circ} \mathbf{C}\right)\end{array}$ & 01.18 & 07.57 & 07.08 \\
$\begin{array}{l}\text { Chloroform } \\
\text { Ethyl }\end{array}$ & 02.60 & 05.54 & 03.98 \\
acetate & 02.26 & 04.47 & 02.02 \\
$\begin{array}{l}\text { Methanol } \\
\text { Water }\end{array}$ & 11.56 & 19.54 & 16.40 \\
\hline *Average of 5 readings were taken & 30.06 & 21.53 \\
\hline
\end{tabular}

TANG / www.e-tang.org

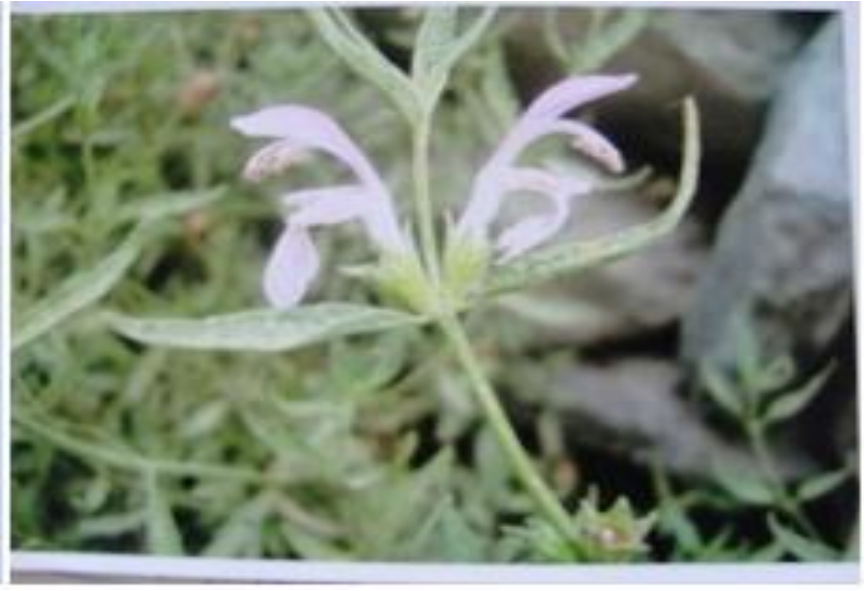

measured $100 \mathrm{ml}$ of distilled water, filtered and the $\mathrm{pH}$ of the filtrate checked with a standardized glass electrode (Chaudhari, 1996; Anonymous, 1996; Mukherjee, 2002; Anonymous, 1998).

\section{Powdered drug reaction with different reagents}

The powdered drug was treated separately with different reagents and acids including picric acid, hydrochloric acid, nitric acid, iodine, ferric chloride, and sodium hydroxide. The colour shown after the treatment was noted (Sama et al., 1994).

\section{Extraction of plant materials}

Whole plant was successively extracted by continuous hot extraction method

Whole plant material was dried in shadow and powdered. The powdered material was passed through sieve no. 40 mesh, weighed \& then used for extraction. The weighed powder was successively extracted with petroleum ether, chloroform, ethyl acetate, methanol in a soxhlet apparatus and the final mark was extracted with water using a decoction method. The resulting extracts were concentrated under reduced pressure using a rotary vacuum evaporator to get the syrupy viscous masses. The viscous masses were transferred to porcelain dishes and dried. The amount of extract was weighed and stored in amber colored airtight bottle at $5-7^{\circ} \mathrm{C}$ (Evans, 2000).

\section{Florescence analysis}

Many herbs show fluorescence when the cut surface or powder is exposed to UV light and this can be useful in their identification. The fluorescence character of the plant powders (40 mesh) was studied both in daylight and UV light (254 and $366 \mathrm{~nm}$ ) and after treatment with different reagents like sodium hydroxide, picric acid, acetic acid, hydrochloric acid, nitric acid, iodine, and ferric chloride (Chase and Pratt, 1949; Kokoshi et al., 1958).

\section{Phytochemical investigation}

After collection and authentication, the plant material was

\begin{tabular}{|c|c|c|}
\hline S.No. & Chemical treatment & Observation \\
\hline 1. & Iodine & Light yellow \\
\hline 2. & Glacial acetic acid & Light green \\
\hline 3. & Ferric chloride 5\% & Buff color \\
\hline 4. & Lead acetate & Yellowish green \\
\hline 5. & Potassium hydroxide $1 \%$ & Light yellow \\
\hline 6. & Picric acid & Yellow \\
\hline 7. & $1 \mathrm{~N} \mathrm{HCl}$ & Buff color \\
\hline 8. & $1 \mathrm{~N} \mathrm{H}_{2} \mathrm{SO}_{4}$ & Reddish brown \\
\hline 9. & $50 \% \mathrm{HNO}_{3}$ & Light yellow \\
\hline
\end{tabular}




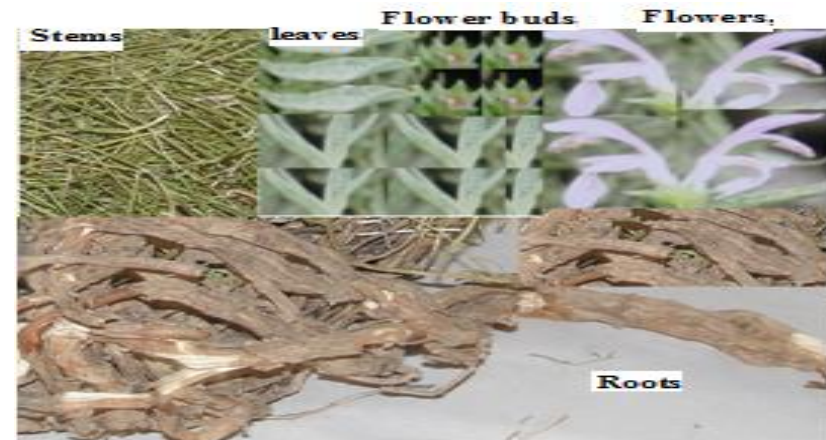

Fig. 2. Stems, leaves, Flower buds, Flowers, Roots of Stachys tibetica Vatke.

shade dried and powdered. It was passed through sieve no. 40 and subjected to extraction. The weighed quantities of plant material were extracted separately with petroleum ether, chloroform, ethyl acetate, methanol and water by a cold extraction method. The plant material was also successively extracted with different solvents like petroleum ether, chloroform, ethyl acetate, methanol in a soxhlet apparatus while the water extract was prepared by decoction. The extracts were evaporated to dryness under reduced pressure and controlled temperature $\left(40-50^{\circ} \mathrm{C}\right)$ (Harborne, 1989). Total methanol extract was also prepared from the drug material by a continuous hot extraction method. The extracts were subjected to preliminary phytochemical investigation for the detection of the following compounds: carbohydrates, protein, amino acids, fats and oils, sterols and steroids, glycoside, coumarins, flavonoids, alkaloids, tannins and phenolic compounds, acidic compounds, saponins, terpenes and terpenoids, mucilage resins and lipids/ fats (Harborne, 1998; Trease and Evans, 1985).

\section{Determination of fat content}

A weighed quantity of the sample $(3 \mathrm{~g})$ was extracted with anhydrous ether in a continuous extraction apparatus for $6 \mathrm{~h}$, and then the extract was filtered into a clean dry weighed flask. The extraction flask was rinsed with a small quantity of ether, filtered and added to the weighed flask. The solvent was evaporated and dried to a constant weight at $105^{\circ} \mathrm{C}$ (Mukherjee, 2002).

\section{Flavonoid determination}

$10 \mathrm{~g}$ of the crude drug powder was extracted repeatedly with $100 \mathrm{ml}$ of $80 \%$ aqueous methanol at room temperature. The whole solution was filtered through Whatman filter paper no. $42(125 \mathrm{~m})$. The filtrate was later transferred into a crucible and evaporated to dryness and weighed to a constant (Boham and Kocipal-Abyazan, 1994).

\section{Saponin determination}

$20 \mathrm{~g}$ of the crude drug was put into a conical flask and 100 $\mathrm{cm}^{3}$ of $20 \%$ aqueous ethanol was added. The sample was heated over a hot water bath for $4 \mathrm{~h}$ with continuous stirring at about $55^{\circ} \mathrm{C}$. The mixture was filtered and the residue reextracted with another $200 \mathrm{ml}$ of $20 \%$ ethanol. The combined extracts were reduced to $40 \mathrm{ml}$ over water bath at about $90{ }^{\circ} \mathrm{C}$. The concentrate was transferred into a $250 \mathrm{ml}$ separatory funnel and $20 \mathrm{ml}$ of diethyl ether was added and shaken vigorously. The aqueous layer was recovered while the ether layer was discarded. The purification process was repeated. $60 \mathrm{ml}$ of $\mathrm{n}$ butanol was added. The combined n-butanol extracts were washed twice with $10 \mathrm{ml}$ of $5 \%$ aqueous sodium chloride. The remaining solution was heated in a water bath to remove the solvent. After evaporation, the sample was dried in an oven to a constant weight and the saponin content calculated (Obadoni and Ochuko, 2001).

\section{Determination of volatile content}

$100 \mathrm{~g}$ of the Stachys tibetica drug was subjected to hydro distillation in a Clevenger apparatus according to the method recommended in British Pharmacopoeia (1988).

\section{Thin layer chromatographical profile of Stachys tibetica}

Steroids/ terpenoids and their glycosides, flavanoids and their glycosides, alkaloids, saponins were detected by using different solvent systems and detecting reagents on precoated TLC plates as mentioned below (Stahl and Sies, 2003, Wagner and Bladt, 1996).

Detection of Steroids/triterpenoids and their glycosides Solvent system used for the detection of steroids and their glycosides are shown in Table 1 and the detecting agent (spraying agent) used are as below.

\section{Spraying reagents:}

(i) Vanillin - Sulphuric acid (VS) reagent:

Solution I: 5\% methanolic sulphuric acid

Solution II: $1 \%$ methanolic vanillin

The developed TLC plate was sprayed with $10 \mathrm{ml}$ of solution 1 , followed immediately by $5-10 \mathrm{ml}$ of solution II, and then heated for $5-10 \mathrm{~min}$ at $110^{\circ} \mathrm{C}$ under observation. Steroids/triterpenoids and their glycosides give blue, blueviolet or pink colored spots.

(ii) Vanillin - Phosphoric acid (VPA) reagent:

Table 5. Fluorescence analysis of Stachys tibetica Vatke

\begin{tabular}{|c|c|c|c|c|}
\hline S. No. & Treatment & Day light & UV light 254nm & UV $366 \mathrm{~nm}$ \\
\hline 1. & Powder & Greyish white & White green & Woody brown \\
\hline 2. & Powder treated with dist. $\mathrm{H}_{2} \mathrm{O}$ & Very light & Light green & Light green \\
\hline 3 & Powder treated with $10 \%$ aq. $\mathrm{NaOH}$ & Yellow green & Light green & Green \\
\hline 4. & Powder treated with $\mathrm{NH}_{3}$ & Light brown & Light green & Green \\
\hline 5. & Powder treated with conc. $\mathrm{H}_{2} \mathrm{SO}_{4}$ & Reddish brown & Dark brown & Green \\
\hline 6. & Powder treated with conc. $\mathrm{H}_{2} \mathrm{SO}_{4}+\mathrm{H}_{2} \mathrm{O}$ & Dark brown & Dark green & Dark green \\
\hline 7. & Powder treated with conc. $\mathrm{HCl}$ & Golden yellow & Light green & Light green \\
\hline 8. & Powder treated with conc. $\mathrm{HCl}+\mathrm{H}_{2} \mathrm{O}$ & Buff color & Light green & Light green \\
\hline 9. & Powder treated with conc. $\mathrm{HNO}_{3}$ & Light yellow & Light green & Light green \\
\hline 10. & Powder treated with conc. $\mathrm{HNO}_{3}+\mathrm{H}_{2} \mathrm{O}$ & Light yellow & Light green & Light green \\
\hline 11. & Powder treated with $5 \%$ Iodine & Light yellow & Green & Light green \\
\hline 12. & Powder treated with 5\% Ferric chloride solution & Greenish black & Light green & black \\
\hline 13. & Powder treated with Picric acid & Yellow & Greenish yellow & Light green \\
\hline 14. & Powder treated with Glacial acetic acid & Light green & Light green & Light pink \\
\hline 15. & Powder treated with petroleum ether & colorless & colorless & Colorless \\
\hline 16. & Powder treated with chloroform & Light green & Light green & Light yellow \\
\hline 17. & Powder treated with ethyl acetate & Light green & Light green & Pink \\
\hline 18. & Powder treated with methanol & Light green & Light green & Light pink \\
\hline
\end{tabular}


Table 6. Phytochemical screening of Stachys tibetica Vatke

\begin{tabular}{|c|c|c|c|c|c|c|c|c|c|c|c|c|}
\hline Solvents & $\begin{array}{l}\text { Carboh } \\
\text { ydrates }\end{array}$ & $\begin{array}{l}\text { Proteins } \\
\text { \& amino } \\
\text {-acids }\end{array}$ & $\begin{array}{l}\text { Lipids / } \\
\text { fats and } \\
\text { oils } \\
\end{array}$ & $\begin{array}{l}\text { Sterols } \\
\text { and } \\
\text { steroids }\end{array}$ & $\begin{array}{l}\text { Glyco } \\
\text { sides }\end{array}$ & $\begin{array}{l}\text { Coum } \\
\text { arins }\end{array}$ & $\begin{array}{l}\text { Sapo } \\
\text { nins }\end{array}$ & $\begin{array}{l}\text { Flavo } \\
\text { noids }\end{array}$ & $\begin{array}{l}\text { Alka } \\
\text { loids }\end{array}$ & $\begin{array}{l}\text { Phenolics } \\
\text { / Tannins }\end{array}$ & $\begin{array}{l}\text { Acidic } \\
\text { comp }\end{array}$ & $\begin{array}{l}\text { Terpenes } \\
\text { and } \\
\text { terpenoids }\end{array}$ \\
\hline \multicolumn{13}{|c|}{ Successive extracts } \\
\hline Pet. ether & + & - & +++ & ++ & - & - & - & - & - & - & ++ & + \\
\hline Chloroform & + & + & ++ & +++ & - & +++ & - & + & + & + & ++ & +++ \\
\hline EA & + & - & - & + & + & + & - & + & - & - & + & + \\
\hline Methanol & ++ & - & - & - & ++ & + & + & +++ & ++ & + & - & - \\
\hline Aqueous & +++ & - & - & - & +++ & - & +++ & + & + & ++ & - & - \\
\hline \multicolumn{13}{|c|}{ Cold extracts (Individual) } \\
\hline Pet. ether & + & - & ++ & ++ & - & - & - & - & - & - & + & - \\
\hline Chloroform & - & - & + & ++ & - & + & - & - & + & - & + & +++ \\
\hline EA & - & - & - & - & - & - & - & + & - & - & + & - \\
\hline Methanol & ++ & + & - & + & + & + & ++ & ++ & + & + & + & + \\
\hline Aqueous & ++ & - & - & - & - & - & +++ & ++ & + & + & - & - \\
\hline \multicolumn{13}{|c|}{ Extract by continuous hot extraction process } \\
\hline $\begin{array}{l}\text { Total } \\
\text { methanolic } \\
\text { extract }\end{array}$ & ++ & + & + & +++ & ++ & +++ & ++ & +++ & + & +++ & + & ++ \\
\hline
\end{tabular}

*Average of 5 readings were taken, $(+++)$ Very strongly positive, $(++)$ Strongly positive, $(+)$ Positive test, $(-)$ Negative test, Pet. Ether $=$ Petroleum ether, Ethyl acetate $=$ EA

Solution a: $1 \mathrm{gm}$ vanillin dissolved in $100 \mathrm{ml}$ of $50 \%$ phosphoric acid.

Solution b: 2 parts $24 \%$ phosphoric acid and 8 parts $2 \%$ methanolic vanillic acid.

After spraying with either solution a or $b$, the plate was heated for $10 \mathrm{~min}$ at $100^{\circ} \mathrm{C}$. A red-violet colour indicates the presence of steroids/ triterpenoids and their glycosides.

(iii) Antimony (III) chloride reagent:

$20 \%$ solution antimony (III) chloride in chloroform.

The developed TLC plate was sprayed with the reagent and then heated for $5-6 \mathrm{~min}$ at $100^{\circ} \mathrm{C}$. There was a red - violet colour in visible light and a red - violet, blue and green fluorescence in UV at $365 \mathrm{~nm}$ indicating the presence of steroids/triterpenoids and their glycosides.

(iv) Anisaldehyde - sulphuric acid reagent:

$0.5 \mathrm{ml}$ of anisaldehyde was mixed with $10 \mathrm{ml}$ glacial acetic acid, followed by $85 \mathrm{ml}$ of methanol and $5 \mathrm{ml}$ of concentrated sulphuric acid, in that order. The developed TLC plate was sprayed with the reagent, heated at $100^{\circ} \mathrm{C}$ for $5-10 \mathrm{~min}$.

Steroids /triterpenoids and their glycosides give blue, blueviolet or pink coloured spots.

\section{Detection of flavonoids and their glycosides}

Solvent system used for detection of flavonoids and their glycosides glycosides are shown in Table 1 and the detecting agents used are as below.

\section{Detection}

The developed TLC plate was observed in visible light and in $\mathrm{UV}$ at $365 \mathrm{~nm}$. Flavonoids and their glycosides appear as yellow, dark blue, orange zones /spots. The color gels intensified on exposure of the plates to ammonia vapors.

\section{Detection of alkaloids}

Solvent systems used for the detection of alkaloids are shown in Table 1 and the detecting agent used is as below.

\section{Detection}

Dragendroff's reagent: The developed TLC plate was sprayed with the reagent and then heated for $5-6 \mathrm{~min}$ at $100^{\circ} \mathrm{C}$.

\section{Detection of saponins}

Solvent systems used for detection of saponins are shown in Table 1 and the detecting agent used is as below.

\section{Detection}

Anisaldehyde - sulphuric acid reagent: The developed TLC plate was sprayed with the reagent, heated at $100^{\circ} \mathrm{C}$ for $5-10$ $\min$.

\section{RESULTS}

Pharmacognostical studies of Stachys tibetica Vatke

The herb is an erect perennial or diffuses annually, rarely sub shrubs or shrubs, sometimes rhizomatous and commonly known as Yakjak, Yagzes (Leh and Ladakh). This is used for the treatment of various diseases. The plant is shown in Fig.1.

\section{Organoleptic study of Stachys tibetica Vatke}

The organoleptic characteristics of Stachys tibetica Vatke are shown in Fig. 2 and Table 2.

\section{Physicochemical constants}

\section{Cold extractive value}

The cold extractive values of the whole plant material in different solvents (individual) are shown in Table 3.

\section{Hot extractive values}

The hot extractive values of the whole plant material in different solvents (individual) are shown in Table 3.

\section{Successive extractive values}

The successive extractive values of the whole plant material in different solvents (individual) are shown in Table 3.

\section{Ash value}

The ash values of Stachys tibetica Vatke were found as total ash $=6.72 \%$, acid insoluble ash $=1.09 \%$ and water soluble ash $=2.83$.

\section{Foreign matter analysis}

The foreign matter in the whole plant material of Stachys tibetica Vatke was found as $0.01 \%$.

\section{Foaming index}

Foaming index was calculated to be more than 100 .

\section{Loss on drying}

Loss on drying in stachys tibetica vatke powder was found as $8.1568 \%$. 
Table 7. Identification of compounds with Thin layer chromatography profile (TLC)

\begin{tabular}{|c|c|c|c|c|c|c|}
\hline Compound & Rf value & $\begin{array}{l}\text { Result } \\
\text { Pet. ether }\end{array}$ & Chloroform & Ethyl acetate & Methanol & water \\
\hline \multicolumn{7}{|c|}{ Extracts of Stachys tibetica Vatke. } \\
\hline Terpenes & 0.39 & + & + & + & + & + \\
\hline Flavonoids & 0.80 & - & + & + & + & + \\
\hline Alkaloids & 0.52 & - & + & - & + & + \\
\hline Steroids & 0.47 & + & + & - & + & - \\
\hline Saponins & 0.55 & - & - & - & + & + \\
\hline \multicolumn{7}{|c|}{ Successive extracts of Stachys tibetica Vatke } \\
\hline Terpenes & 0.39 & + & + & - & + & - \\
\hline Flavonoids & 0.80 & - & - & + & + & + \\
\hline Alkaloids & 0.52 & - & + & - & + & + \\
\hline Steroids & 0.47 & + & + & - & - & - \\
\hline Saponins & 0.55 & - & - & - & + & + \\
\hline
\end{tabular}

\section{Swelling index}

Swelling index was found to be 3 .

pH Values

The $\mathrm{pH}$ values of $1 \%$ and $10 \%$ solution were 6.59 and 6.34 respectively.

\section{Powdered drug reaction with different reagents}

The powdered drug was reacted with reagents and the results are shown in Table 4.

\section{Fluorescence analysis}

The powder of the whole plant of Stachys tibetica Vatke (mesh size 40) was examined under daylight and UV light. The observations are shown in Table 5.

Phytochemical screening of successive extracts

The phytochemical screening of successive extracts of Stachys tibetica Vatke is shown in Table 6.

\section{Phytochemical screening of cold extracts}

The phytochemical screening of cold extracts of Stachys tibetica Vatke is shown in Table 6.

\section{Phytochemical screening of Total methanol extract}

The whole plant of Stachys tibetica Vatke was extracted with methanol using a soxhlet apparatus and subjected to phytochemical screening which results in the class of phytochemicals (Table 6).

\section{Fat and volatile content of Stachys tibetica Vatke}

The fat and volatile contents of Stachys tibetica Vatke were determined as $6.5 \%$ and $0.7 \%$ respectively.

Flavonoid and saponin content of Stachys tibetica Vatke

The flavonoid and saponin contents of of Stachys tibetica Vatke were determined as $54.7 \mathrm{mg} / \mathrm{g}$ and $75.4 \mathrm{mg} / \mathrm{g}$.

\section{Thin layer chromatography profile}

The TLC of extracts and successive extracts of Stachys tibetica Vatke showed the presence of compounds (Table 7).

\section{DISSCUSSION}

The indigenous or traditional system of medicine has gained importance in the field of medicine. A large number of populations depend on traditional practitioners, who in turn are dependent on medicinal plants, to meet their primary health care needs. As the usage of these herbal medicines has increased, issues and the motto regarding their quality, safety, and efficacy in industrialized and developing countries have cropped up (Kumar et al., 2010). Increasing interest has forced the researchers to scientifically screen various traditional claims. Therefore, at present, both common users and healthcare professionals seek updated, alterative information regarding the safety and efficacy of any recommended medicinal plant as a drug prior to its use (Bhat et al., 2011).

The relevance of pharmacognosy in the standardization of herbal drugs was been long been stressed. Many monographs on pharmacognostic parameters have emerged as an aid in the pharmacognostic investigations. These studies help in the identification and authentication of the plant material. Medicinal plant materials are categorized according to sensory, macroscopic and microscopic characteristics. An examination to determine these characteristics is the first step towards establishing the identity and degree of purity of such materials.

The extractive value is used to determine the amount of active constituents extracted with solvents. Ash values are used to determine the extraneous matter, such as sand and soil, adhering to the plant surface. Fluorescence is an important phenomenon exhibited by various chemical constituents present in plant material. Some constituents show fluorescence in the visible range in many natural products (e.g., alkaloids like berberine), which do not visibly fluoresce in day light. If the substances themselves are not fluorescent, they may often be converted into fluorescent derivatives by applying different reagents, hence some crude drugs are often assessed qualitatively in this way and it is an important parameter of the pharmacognostical evaluation (Ansari, 2006).

In the present investigation various standardization parameters such as organoleptic and physico-chemical parameters, fluorescence analysis, powdered drug reaction with different reagents, phytochemical screening and TLC analysis, saponin, fat, and flavonoid content were implemented which could be helpful in the authentification of Stachys tibetica Vatke. The results of the present study will also serve as reference material in the preparation of the monograph.

\section{ACKNOWLEDGMENTS}

Dinesh Kumar, ZA Bhat, and MY Shah would like to thank the Department of Pharmaceutical Sciences, University of Kashmir, Jammu and Kashmir, India, and UGC-Delhi for their interest and financial help with this manuscript.

\section{CONFLICT OF INTEREST}

The authors have no conflicting financial interests.

\section{REFERENCES}


Anonymous. Quality Control Methods for Medicinal Plant Material. WHO Geneva. 1998;8:78.

Anonymous. The Ayurvedic Pharmacopoeia of India. Vol. I, Ministry of Health and Family Welfare, Department of Yoga \& Naturopathy, Unani and Siddha, New Delhi. 1996.

Ansari SH. Essentials of pharmacognosy. $1^{\text {st }}$ ed. (New Delhi, India: Birla Publications Pvt. Ltd), 2006.

Ballabh B, Chaurasia OP. Traditional medicinal plants of cold desert Ladakh-Used in treatment of cold, cough and fever. J Ethnopharmacol. 2007;112:341-349.

Bhat ZA, Kumar D, Shah MY. Angelica archangelica linn. is an Angel on earth for the treatment of diseases: A review. Int $\mathbf{J}$ Nutr Pharmacol Neurol Dis. 2011;1:35-49.

Boham BA, Kocipal- Abyazan R. Flavonoids and condensed tannins from leaves of Hawaiian vaccinium vaticulatum and $V$. calycinum. Pac Sci. 1994;48:458-463.

British Pharmacopoeia. (London, United Kingdom: HMSO Electronic Publishing), pp. 137-138, 1988.

Chaudhari RD. Herbal drug industry. $1^{\text {st }}$ ed. (New Delhi, India: Eastern Publishers), 1996.

Trease GE, Evans WC. Pharmacognosy. (New York,USA: Saunders Publishers), pp. 97-105, 2000.

Harborne JB. Phytochemical methods In: A guide to modern techniques of plant analysis. $3^{\text {rd }}$ ed. (London, U.K.: Chapman and Hall), pp. 56-99,1998.

Hartwell JL. Plants used against cancer. A survey. (Massachusetts, USA: Quarterman Publications Inc.), 1982.
Kokoshi J, Kokoski R, Slama FJ. Fluorescence analysis of powedred vegetable drugs under ultraviolet radiation. J Am Pharm Assoc. 1958;47:75-77.

Kumar D, Bhat ZA, Singh P, Khatanglakar V, Bhujbal SS. Antiasthmatic and antiallergic potential of methanolic extract of leaves of Ailanthus excelsa Roxb., Simaroubaceae. Braz J Pharmacogn. 2011;21:139-145.

Kumar D, Bhat ZA, Singh P, Shah MY, Bhujbal SS. Ailanthus excelsa Roxb. is Really a Plant of Heaven. Int J Pharmacol. 2010;6:535-550.

Mabberley DJ. The Plant-book. A Portable Dictionary of the Vascular Plants, $2^{\text {nd }}$ ed. (Cambridge, England: Cambridge University Press), 1997.

Mukherjee PK. Quality Control of Herbal Drugs. (New Delhi, India: Business Horrizons), pp. 132-191, 2002.

Mulla SK, Swamy P. Preliminary Pharmacognostical and Phytochemical evaluation of Portulaca quadrifida Linn. Int J Pharm Tech Res. 2010;2:1699-1702.

Obadoni BO, Ochuko PO. Phytochemical studies and comparative efficacy of crude extracts of some homeostatic plants in Edo and Delta States of Nigeria. Global J Pure \& Appl Sci. 2001;8:203-208.

Sama V, Swamy MM, Vijayalakshmi S, Reddy YSR, Suresh B. Pharmacognostical observation on Sida rhomboidea. A report. Indian Drugs. 1994;3:421-429.

Stahl W, Sies H. Antioxidant activity of Carotenoids. Mol Asp Med. 2003;24:345-351.

Wagner H, Bladt S. Plant Drug Analysis; $2^{\text {nd }}$ ed. (New York, USA: Springer), pp. 349-364, 1996. 